\title{
DISTRIBUSI DAN KELIMPAHAN FITOPLANKTON DI TELUK GERUPUK, NUSA TENGGARA BARAT
}

\author{
Sri Endah Purnamaningtyas, Mujiyanto dan Riswanto \\ Balai Riset Pemulihan Sumberdaya Ikan \\ Email: endah_purnamaningtyas@yahoo.co.id
}

\begin{abstract}
ABSTRAK
Penelitian dilakukan di perairan Teluk Gerupuk pada bulan April, September 2015 dan Mei 2016 dengan tujuan untuk mengetahui distribusi dan kelimpahan fitoplankton di Teluk Gerupuk Nusa Tenggara Barat. Metode yang digunakan untuk menghitung kelimpahan fitoplankton menggunakan" Sedgewick-Rafter Counting Cell" dan analisis kualitas air merujuk pada APHA (2005). Penelitian di lakukan di 9 (Sembilan) stasiun penelitian dengan hasil kelimpahan fitoplankton berkisar antara: 619.958 - 7.456 .476 sel/l; yang terdiri dari 2 kelas fitoplankton yaitu: Kelas Bacillariophycea, terdapat 32 jenis dan Kelas Dinophyceae terdapat 5 jenis yang ditemukan pada 9 (sembilan) stasiun pengamatan dengan lima jenis diatom potensial, yaitu Coscinodiscus sp., Chaetoceros sp., Nitzschia sp., Pleurosigma sp., dan Bidduphia sp. Berdasarkan indeks biologi terlihat bahwa kelimpahan tertinggi dan dominansi fitoplankton dari genus Chaetoceros sp. Keanekaragaman fitoplankton yang rendah dengan kisaran 0,24-98 dengan rata-rata 0,58 $\pm 0,29$, dan keseragaman fitoplankton berkisar antara: 0,01-0,05 dengan rata-rata $0,03 \pm 0,02$ atau dengan kata lain $0<\mathrm{E}<0,5$ berarti komunitas fitoplankton tertekan.
\end{abstract}

Kata kunci: Fitoplankton, Kualitas Lingkungan, Teluk Gerupuk

\section{DISTRIBUTION AND ABUNDANCE OF FITOPLANKTON IN THE GERUPUK BAY, WEST NUSA TENGGARA}

\begin{abstract}
The study was conducted in the waters of Gerupuk Bay in April, September 2015 and May 2016 with the aim of finding out the distribution and abundance of phytoplankton in Gerupuk Bay, West Nusa Tenggara. The method used to calculate the abundance of phytoplankton using "Sedgewick-Rafter Counting Cell" and water quality analysis refers to APHA (2005). The study was conducted at 9 (nine) research stations with an abundance of phytoplankton results ranging from: 619,958 7,456,476 cells /L; consisting of 2 phytoplankton classes namely: Bacillariophycea class, there are 32 species and Dinophyceae class there are 5 species found in 9 (nine) observation stations with five types of potential diatoms, namely Coscinodiscus sp., Chaetoceros sp., Nitzschia sp., Pleurosigma sp., and Bidduphia sp. Based on the biological index shows that the highest abundance and phytoplankton dominance of the genus Chaetoceros sp. Phytoplankton diversity is low in the range of 0.24-98 with an average of $0.58 \pm 0.29$, and phytoplankton uniformity ranges between: $0.01-0.05$ with an average of $0.03 \pm 0.02$ or in words another $0<\mathrm{E}<0.5$ means that the phytoplankton community is depressed
\end{abstract}

Keywords: Phytoplankton, Environmental Quality, Gerupuk Bay

\section{PENDAHULUAN}

Berdasarkan Peraturan Bupati No. 2 Tahun 2011, kawasan Teluk Gerupuk ditetapkan sebagai Kawasan Konservasi Laut Daerah (KKLD) Lombok Tengah Kabupaten Lombok Tengah Provinsi Nusa Tenggara Barat. KKLD yang dibentuk disepakati menjadi Taman Wisata Perairan dengan zona inti di daerah karang yang diharapkan fungsinya nanti sebagai tempat pemijahan lobster dan ikan laut lainnya sehingga dapat menyuplai larva lobster dan ikan lainnya ke daerah pemanfaatan.

Kawasan KKLD ini memiliki tiga ekosistem, yaitu: ekosistem mangrove, padang lamun, dan terumbu karang sehingga pada kondisi tersebut biasanya memiliki produktivitas yang sangat tinggi. Menurut Gunarto (2004) ekosistem mangrove mempunyai fungsi antara lain, sebagai: 1.perputaran unsur hara, produktivitas yang tinggi berasal dari kegiatan penduduk di pesisir teluk, 2. Sebagai habitat dari berbagai macam biota dan juga merupakan daerah penyangga antara ekosistem darat dan laut.

Bertambahnya pemukiman penduduk, kegiatan industri rumah tangga dan usaha pertanian serta peternakan dapat berpengaruh terhadap kualitas air, karena limbah yang dihasilkan dari kegiatan tersebut umumnya langsung dibuang ke perairan yang akan mengakibatkan terjadinya perubahan faktor fisika, kimia dan biologi di perairan tersebut.

Salah satu organisme yang hidup di ekosistem perairan pesisir adalah fitoplankton. Fitoplankton di dalam ekosistem perairan berperan sebagai pengubah zat-zat anorganik menjadi zat-zat organik melalui proses fotosintesis, yang kemudian dapat menentukan produktivitas perairan dan kesuburan perairan (Mann \& Lazier 1991) yang terdapat pada lapisan permukaan air laut (Andrew \& Finkel 2008). Proses fotosintesis itu sendiri dapat dijadikan indikator tinggi rendahnya produktivitas suatu perairan dan dapat memberikan informasi tentang ketersediaan nutrient di perairan (Ornolfsdottir et al., 2004).

Kelimpahan dan konsentrasi fitoplankton dipengaruhi oleh faktor fisika-kimia (Sin et al. 1999) dan ketersediaan nutrien yang merupakan faktor pembatas produksi fitoplankton, di perairan (Struyf $e t$ al., 2009; Barbiero et al., 2006; Depew et al., 2006 ). Dimana nutrien merupakan senyawa yang sangat dibutuhkan oleh oranisme laut dalam metabolism, proses fisiologis, dan reakksi biolimiawi (Chen, 
2007). Berdasarkan hal tersebut diatas, maka tujuan penelitian ini adalah untuk mengetahui distribusi dan kelimpahan fitoplankton di Teluk Gerupuk

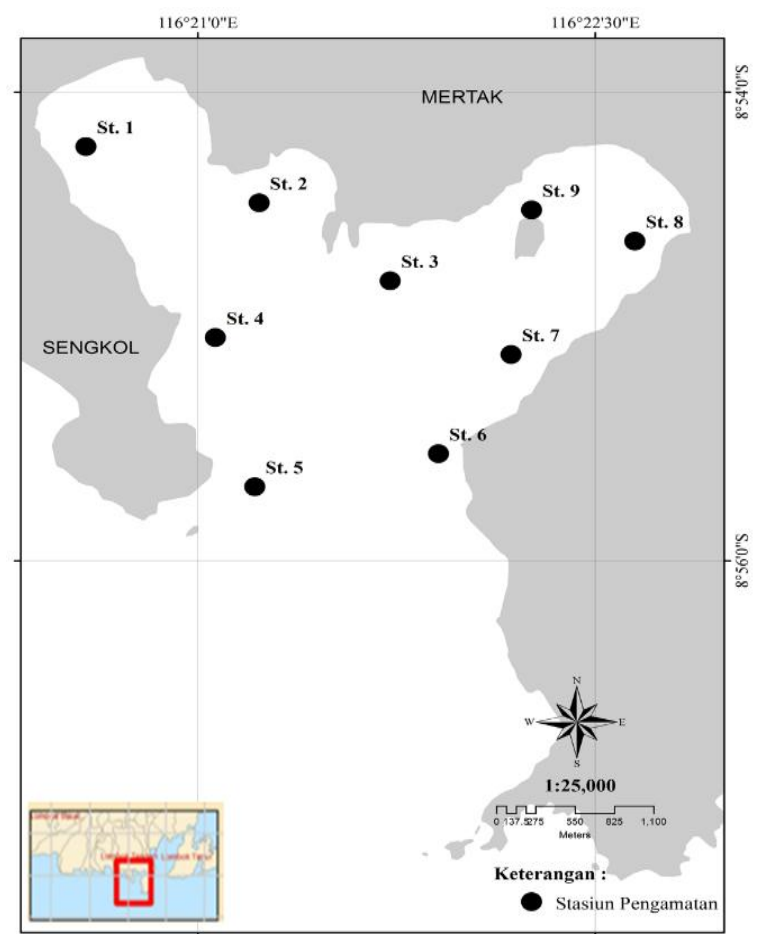

Gambar 1. Stasiun penelitian di Teluk Gerupuk, Nusa Tenggara Barat

\section{METODE}

Penelitian ini dilaksanakan dari bulan April, September 2015 dan Mei 2016. Pengambilan sampel dilakukan di 9 (sembilan) stasiun penelitian (Gambar 1), Nusa Tenggara Barat. Penentuan titik sampling menggunakan metode purposive sampling yang didasarkan pada karakteristik lingkungan. Pengambilan sampel plankton diambil pada permukaan perairan yang ditarik sepanjang $7 \mathrm{~m}$ dengan kecepatan konstan.

Parameter yang diamati meliputi parameter fisika dan kimia (Tabel.1) dan fitoplankton. Fitoplankton dikumpulkan dengan menggunakan fitoplankton net ukuran $76 \mu \mathrm{m}$. Sampel plankton yang diperoleh kemudian disimpan dalam botol dan diawetkan menggunakan formalin $4 \%$. Pada setiap mulut jaring plankton dilengkapi dengan "flowmeter" untuk mengukur volume air yang masuk kedalam jaring. Pengukuran volume air tersaring dihitung dengan rumus:

$$
\mathrm{V}=\mathrm{R} \text {. a. } \mathrm{p}
$$

Keterangan:

$\mathrm{V}$ : volume air tersaring ( $\mathrm{m} 3)$

$\mathrm{R}$ : Jumlah rotasi baling-baling flowmeter

$\mathrm{a}:$ luas mulut jaring

$\mathrm{p}$ : panjang kolom air ( $\mathrm{m}$ ) yang ditempuh untuk satu rotasi

Tabel 1. Parameter fisika, kimiawi dan fitoplankton yang diamati

\begin{tabular}{|c|c|c|c|}
\hline No & Parameter & Satuan & Alat/Bahan dan Metode (APHA, 2005) \\
\hline \multirow[t]{2}{*}{ A. } & Kualitas Air & & \\
\hline & Fisika & & GPS Garmin, insitu \\
\hline 1 & Suhu air & ${ }^{\circ} \mathrm{C}$ & WQC Horiba, insitu \\
\hline 2 & $\mathrm{pH}$ & unit & WQC Horiba, insitu \\
\hline \multirow[t]{2}{*}{3} & Salinitas & $\%$ & WQC Horiba, insitu \\
\hline & Kimiawi & & \\
\hline 1 & Oksigen terlarut & $\mathrm{mg} / \mathrm{L}$ & WQC Horiba, insitu \\
\hline 2 & Nitrat & $\mathrm{mg} / \mathrm{L}$ & Brucine sulfat/spektrofotometri \\
\hline 3 & Orthofosfat & $\mathrm{mg} / \mathrm{L}$ & Stannous chloride/spektrofotometri \\
\hline 1 & Plankton & & \\
\hline 11 & Fitoplankton & $\mathrm{sel} / \mathrm{L}$ & $\begin{array}{l}\text { Fitoplankton dikumpulkan menggunakan } \\
\text { fitoplankton net berbentuk kerucut dengan } \\
\text { diameter mulut } 31 \mathrm{~cm} \text {, panjang } 100 \mathrm{~cm} \text { dan } \\
\text { ukuran mata jaring } 0,08 \mathrm{~mm}(80 \mu \mathrm{m}) \text {. Sampel } \\
\text { plankton yang diperoleh kemudian disimpan } \\
\text { dalam botol dan diawetkan menggunakan } \\
\text { formalin } 4 \% \text {. }\end{array}$ \\
\hline
\end{tabular}


Analisis untuk parameter kualitas air dilakukan dilapangan (insitu) seperti: suhu air, $\mathrm{pH}$, salinitas dan $\mathrm{O}_{2}$ terlarut menggunakan Water Quality Checker Horiba U 50. Sedangkan untuk analisis $\mathrm{N}^{-\mathrm{NO}_{3}}$ dan $\mathrm{P}_{-} \mathrm{PO}_{4}$ menggunakan Spektrofotometer. Sampel air diambil dengan menggunakan "Kemmerer Bottle Sample " dengan Volume air 4,2 liter. Sampel air dimasukkan kedalam botol dengan volume $500 \mathrm{ml}$ sampel kemudian dianalisis dan di laboratorium Balai Riset Pemulihan Sumberdaya Ikan. Demikian juga dengan Sampel plankton diidentifikasi dengan menggunakan mikroskop high power. Pencacahan plankton dilakukan dengan menggunakan "Sedgewick-Rafter Counting Cell" atas fraksi sampel dan untuk hasilnya dinyatakan dalam sel/m3. Penentuan kelimpahan plankton menggunakan metode Lackey drop microtransect counting (APHA, 2005) dengan persamaan sebagai berikut::

$$
\mathrm{N}=(\mathrm{n} / \mathrm{p}) \times(\mathrm{A} / \mathrm{B}) \times(\mathrm{C} / \mathrm{B}) \mathrm{X}(1 / \mathrm{E})
$$

Keterangan :

$\mathrm{N}=$ Kelimpahan fitoplankton (sel/l)

$\mathrm{n}=$ Jumlah individu yang tercacah (sel/l)

$\mathrm{p}=$ Jumlah pengamatan

A = Luas gelap penutup $(\mathrm{mm} 2)$

$\mathrm{B}=$ Luas lapang pandang $(\mathrm{mm} 2)$

$\mathrm{C}=$ Volume air terkonsentrasi $(\mathrm{ml})$

$\mathrm{D}=$ Volume air satu tetes $(\mathrm{ml})$ dibawah gelas penutup

$\mathrm{E}=$ Volume air yang disaring (1)

Keanekaragaman dianalisis dengan menggunakan rumus Shannon - Wiener (Setyobudiandi dan B, Priyono 2009) sebagai berikut:

$$
H^{\prime}=-\sum_{i=1}^{n}(n i / N) \ln (n i / N)
$$

Dimana:

$\mathrm{H}=$ Indeks keanekaragaman

ni $=$ jumlah individu spesies $\mathrm{ke}-\mathrm{i}$

$\mathrm{N}=$ jumlah individu seluruh spesies

Dengan kriteria

$\mathrm{H}^{\prime}<1=$ keanekaragaman rendah

$1<\mathrm{H}^{\prime}<3$ = keanekaragaman sedang

$\mathrm{H}^{\prime}>3=$ keanekaragaman tinggi

Indeks keseragaman menggambarkan jumlah kemerataan individu pada beberapa jenis biota.
Indeks keseragaman dihitung berdasarkan (Setyobudiandi dan B, Priyono, 2009), sebagai berikut:

Dimana:

$$
E=\frac{H^{\prime}}{\log _{2} S}
$$

$\mathrm{E}=$ Indeks keseragaman

$\mathrm{H}^{\prime}=$ Indeks keanekaragaman Shannon Wiener

$\mathrm{S}=$ Jumlah spesies

Sedangkan indeks dominansi dianalisis dengan rumus dari (Odum, 1993), sebagai berikut:

$$
C=\sum_{i=1}^{n}\left(\frac{n i}{N}\right)^{2}
$$

Dimana:

$$
\begin{aligned}
& \mathrm{C}=\text { indeks dominansi } \\
& \text { ni }=\text { jumlah individu spesies ke-i } \\
& \mathrm{N}=\text { jumlah total individu }
\end{aligned}
$$

Dengan kriteria:

$0<\mathrm{C} \leq 0,5$ : Dominansi rendah

$0,5<\mathrm{C}<1$ : Dominansi tinggi

\section{HASIL DAN PEMBAHASAN}

Pengukuran kualitas perairan seperti: suhu air, salinitas, $\mathrm{pH}, \mathrm{DO}, \mathrm{N}-\mathrm{NO}_{3}$ dan $\mathrm{P}_{-} \mathrm{PO}_{4}$ disajikan dalam Tabel. 2, dimana pengaruh kualitas perairan yang ada di pesisir tergantung kepada kegiatankegiatan yang ada disekitarnya, seperti: industri, rumah tangga dan berbagai kepentingan lainnya sangat mempengaruhi kualitas air dan pertumbuhan fitoplanktonnya. Kisaran suhu air selama penelitian berkisar antara: $27,3-29,26^{\circ} \mathrm{C}$ dengan nilai rata-rata 28,14. Nilai salinitas berkisar antara: 30,65-36,40\%o dengan nilai rata-rata 32,1. Menurut (Fong dan Geyer., 2001., Kalangi et.at., 2012) sebaran salinitas dipengaruhi oleh pola sirkulasi air, penguapan, curah hujan dan air sungai. Nilai pH tidak menunjukkan variasi yang menyolok, yaitu berkisar antara: 7,958,58 rata-rata 8,26 . Nilai $\mathrm{pH}$ terendah terdapat di stasiun Gerupuk 7 dan tertinggi terdapat di stasiun Gerupuk 3. Oksigen terlarut selama penelitian berkisar antara: 5,76-7,45 mg/L dengan rata-rata 6,63 $\mathrm{mg} / \mathrm{L}$, rata-rata konsentrasi oksigen di perairan gerupuk cukup tinggi.

Tabel 2. Rata-rata parameter fisika kimia di Teluk Gerupuk selama Penelitian

\begin{tabular}{|l|r|r|r|r|r|r|r|r|r|}
\hline & Gerupuk 1 & Gerupuk 2 & Gerupuk 3 & Gerupuk 4 & Gerupuk 5 & Gerupuk 6 & Gerupuk 7 & Gerupuk 8 & Gerupuk 9 \\
\hline Suhu Air $\left({ }^{\circ} \mathrm{C}\right.$ ) & 29.26 & 28.00 & 28.26 & 27.64 & 28.29 & 27.60 & 27.30 & 28.46 & 28.49 \\
\hline Salinitas (\%o) & 31.00 & 30.65 & 30.65 & 30.65 & 36.40 & 32.37 & 35.90 & 30.65 & 30.65 \\
\hline $\mathrm{pH}$ (unit) & 8.39 & 8.14 & 8.58 & 8.02 & 8.07 & 8.52 & 7.95 & 8.34 & 8.29 \\
\hline $\mathrm{O}_{2}$ (mg/l) & 6.58 & 7.10 & 6.90 & 7.45 & 6.47 & 6.51 & 5.76 & 6.15 & 6.78 \\
\hline $\mathrm{N}-\mathrm{NO}_{3}$ (mg/l) & 0.129 & 0.195 & 0.163 & 0.625 & 0.549 & 0.136 & 0.536 & 0.536 & 0.530 \\
\hline $\mathrm{P}_{-} \mathrm{PO}_{4}$ (mg/l) & 0.056 & 0.950 & 0.031 & 0.033 & 0.024 & 0.014 & 0.037 & 0.426 & 0.033 \\
\hline
\end{tabular}


Kandungan zat hara seperti fosfat dan nitrat (nutrient) akan semakin meningkat dengan bertambahnya kedalaman, menurut Asriyana dan Yuliana (2007), cahaya matahari semakin berkurang dengan bertambahnya kedalaman perairan, hal ini menyebabkan nilai produktivitas primernya semakin rendah. Energi cahaya matahari digunakan dalam proses fotosintesis, diserap oleh pigmen klorofil dan diubah menjadi energi kimia yang digunakan dalam proses reduksi karbondioksida sehingga terbentuk bahan organik sebagai hasil akhir fotosintesis.

Keberadaan fosfat dan nitrat di perairan sangat penting karena merupakan faktor pembatas serta berpengaruh terhadap produktifitas fitoplankton (Haumau, 2005). Konsentrasi $\mathrm{N}-\mathrm{NO}_{3}$ dan $\mathrm{P}_{-} \mathrm{PO}_{4}$ yang merupakan nutrien utama dan dibutuhkan bagi pertumbuhan fitoplankton. Konsentrasi $\mathrm{N}^{-\mathrm{NO}_{3}}$ di perairan Teluk Gerupuk berkisar antara 0,129-0,625 $\mathrm{mg} / \mathrm{L}$, konsentrasi $\mathrm{N}-\mathrm{NO}_{3}$ terendah terdapat di stasiun gerupuk 2 dan tertinggi terdapat di stasiun gerupuk 4, hasil penelitian ini memiliki nilai tingkat maksimum yang lebih rendah bila dibandingkan dengan penelitian Purnamaningtyas, et al., (2017) di Kabupaten Kubu Raya yaitu sebesar 1,41 mg/ L dan lebih rendah lagi bila dibandingkan dengan hasil penelitian Camargo, J.A et al., (2005) sebesar 20 $\mathrm{mg} / \mathrm{L}$ dan lebih tinggi bila dibandingkan dengan hasil penelitian Meirinawati dan Nurul Fitriya (2018) di perairan Halmahera yaitu sebesar 0,074 mg/L

Unsur hara seperti nitrogen dan fosfor merupakan faktor utama bagi pertumbuhan fitoplankton di perairan beriklim tropis (DiTullio et al., 1993 dan Fried et al., 2003), biomassa (Dugenale \& Wilkerson 1992, Graziano et al., 1996). Penelitian pada 9 stasiun pengamatan, didapatkan kandungan nitrat berada pada kisaran 0.077-0.323 mg/L. Konsentrasi nitrat di perairan ini lebih rendah daripada hasil penelitian Camargo, J.A et al. (2005) yang memiliki nilai tingkat maksimum NO3 sebesar $20 \mathrm{mg} / \mathrm{L}$ dan masih dapat diterima bagi kehidupan biota laut. Kadar nitrat yang lebih dari $0,2 \mathrm{mg} / \mathrm{l}$ dapat mengakibatkan terjadinya eutrofikasi, selanjutnya menstimulir pertumbuhan algae secara pesat (blooming) (Effendi, 2003).

Konsentrasi fosfat berada pada kisaran 0,0260,950 mg/L. Sanusi (1994) menyatakan bahwa kebutuhan optimum bagi pertumbuhan fitoplankton, kisaran ortofosfat yang adalah 0,09-1,80 mg/L. Mackentum (1969) in Basmi (1999) senyawa ortofosfat merupakan faktor pembatas bila kadarnya di bawah 0,004 ppm, sementara pada kadar lebih dari 1,0 ppm PO4-P dapat menimbulkan blooming.

Hasil analisis kelimpahan fitoplankton di sekitar Teluk Gerupuk dan Bumbang selama penelitian berkisar antara $619.958-7.456 .476 \mathrm{sel} / \mathrm{L}$. Kelimpahan terendah terdapat di Stasiun 5 dan tertinggi terdapat di stasiun 9 (Gambar 2 dan Tabel 4). Kelimpahan fitoplankton terdiri dari 2 kelas fitoplankton yaitu: 1. Kelas Bacillariophycea: 32 jenis dan 2. Kelas Dinophyceae: 5 jenis, hal tersebut sesuai dengan pendapat (Panda et al., 2012) di pesisir pantai Orissa, Bengal dan menurut Basmi (1999) fitoplankton yang umum terdapat dilaut biasanya berukaran besar dan terdiri dari dua kelompok yang mendominasi di perairan, yaitu: 1. Bacillariophyceae dan 2. Dinoflagellata, dan merupakan jenis fitoplankton yang paling penting dan umum terdapat di laut, sedangkan, Cyanophyceae merupakan jenis fitoplankton yang paling sedikit dijumpai. Hal ini berbeda dengan pendapat Purnamaningtyas, et al., 2017 di perairan Kubu Raya yang teridentifikasi sebanyak 4 (empat) kelas fitoplankton, yaitu: 1 . Cyanophyceae, 2. Chlorophyceae, 3. Bacillariophyceae dan 4. Dinophyceae

\section{Komposisi Jenis}

Selama penelitian terdapat 36 genus fitopankton (Tabel 3) dari 2 (dua) kelas, yaitu kelas Bacillariophyceae (34 genus) dan kelas Dinophyceae (2 genus), (dimana tiap bulan pengamatan mempunyai komposisi kelimpahan fitoplankton yang berbeda (Gambar 2 dan Tabel 4). Ditemukan sebanyak lima jenis diatom potensial, yaitu Coscinodiscus sp., Chaetoceros sp., Nitzschia sp., Pleurosigma sp., dan Bidduphia sp. di ketiga stasiun sampling. Chaetoceros sp. merupakan diatom yang paling melimpah diantara diatom lainnya di setiap stasiun, seperti terlihat pada Tabel 4.

Berdasarkan Tabel.4 terlihat bahwa genus Coscinodiscus sp selama penelitian mempunyai kelimpahan yang cukup besar, yaitu berkisar berkisar antara 53.786 - $224.345 \mathrm{sel} / \mathrm{L}$ kemudian diikuti oleh jenis sebesar chaetoceros sp yang berkisar antara 15.570 - $84.218 \mathrm{sel} / \mathrm{L}$. Hal tersebut sesuai dengan pendapat (Takano 1990; Hasle \& Syvertsen 1997; Qi, 2008; Sediadi \& Wenno. 1995, Putri et.al., 2016) yang menyatakan bahwa Coscinodiscus sp dan Chaetoceros sp merupakan genus diatom yang mendominasi perairan laut dan pesisir.

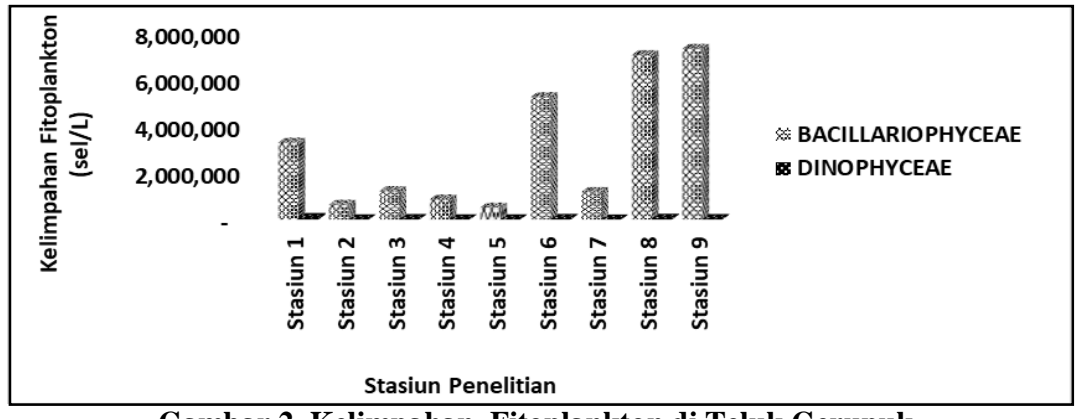

Gambar 2. Kelimpahan Fitoplankton di Teluk Gerupuk 
Tabel 3. Indeks Biologi Fitoplankton

\begin{tabular}{|l|c|c|c|c|r|r|r|r|r|r|}
\hline & Stasiun 1 & Stasiun 2 & Stasiun 3 & Stasiun 4 & Stasiun 5 & Stasiun 6 & Stasiun 7 & stasiun 8 & Stasiun 9 \\
\hline Keanekaragaman & 0.42 & 0.98 & 0.85 & 0.98 & 0.97 & 0.89 & 0.32 & 0.33 & 0.31 \\
\hline Keseragaman & 0.02 & 0.03 & 0.03 & 0.03 & 0.05 & 0.05 & 0.01 & 0.02 & 0.01 \\
\hline Dominansi & 0.65 & 0.21 & 0.24 & 0.15 & 0.16 & 0.20 & 0.73 & 0.71 & 0.75 \\
\hline
\end{tabular}

Tingginya kelimpahan diatom dapat juga disebabkan ketersediaan cahaya, hal tersebut sesuai dengan pendapat (Alpine \& Cloern, 1988) yang mempunyai sifat eurythermal dan euryhaline. Pertumbuhan optimumnya memerlukan suhu pada kisaran antara $25-30^{\circ} \mathrm{C}$ salinitas optimal untuk pertumbuhan Chaetoceros adalah 28-30\% dan memerlukan sinar matahari, dan kekeruhan. Memiliki kelimpahan yang besar hampir sepanjang tahun pada perairan laut, baik di habitat muara maupun pesisir serta selalu menjadi bagian dari ledakan populasi diatom pada musim semi.

Indeks biologi fitoplankton selama penelitian, seperti Indeks Keanekaragaman (H') di berkisar antara: 0,24-98 dengan rata-rata 0,58 $\pm 0,29$, hal tersebut menunjukkan bahwa perairan teluk Gerupuk dan Bumbang berdasarkan indeks keanekragaman Shannon (Odum, 1993) dimana $\mathrm{H}<1$ mempunyai keanekaragaman rendah, keseragaman fitoplankton yang berkisar antara: 0,01-0,05 dengan rata-rata $0,03 \pm 0,02$ atau dengan kata lain $0<\mathrm{E}<0,5$ berarti komunitas fitoplankton tertekan dan indeks dominansi yang berkisar antara 0,15-0,79 dengan rata-rata $0,48 \pm 0,27$ artinya atau $0<\mathrm{C} \leq 0,5$ Tidak ada spesies/genus yang mendominasi (Tabel. 2)
Tabel 4. Genus Fitoplankton Selama Penelitian

\begin{tabular}{lll}
\hline No & Kelas & Genus \\
\hline 1. & Bacillario & Asterionella, \\
& phyceae & Asterolamphalus, \\
& & Amphiprora, Bacillaria,, \\
& Bacteriastrum, Biddulphia, \\
& Chaetoceros, Climacodium, \\
& Climacosphenia, Cococcneis., \\
& Coscinodiscus, Cylindroteca, \\
& Diploneis, Dytilum, \\
& Eucampia, Fragillaria, \\
& Guinardia, Hemiaulus., \\
& Lauderia, Leptocylindrus, \\
& Licmophora., Melosira, \\
& Navicula, Nitzchia, \\
& Pleurosigma, Rhizosolenia, \\
& Skeletonema, Strepthoteca, \\
& Surirella, Striatella, \\
& Triceratium, Thalassiothrix \\
& Ceratium, Dinophysis, \\
Dinophyc & Ornithocercus, \\
eae & Protoperidinium, Pyrophacus \\
\hline
\end{tabular}

Tabel. 5 Kelimpahan Fitoplankton selama penelitian

\begin{tabular}{|c|c|c|c|c|c|c|c|c|c|}
\hline KELAS DAN GENUS & Stasiun 1 Gerur & Serupuk & Stasiun 3 Ger & 4 Gerupuk & Stasiun 5 Geru & Gerupuk & St 7 Bumbang & st 8 Bumbang & St 9 Bumbang \\
\hline BACILLARIOPHYCEAE & $1,643,312$ & 270,347 & 314,225 & 714,084 & 609,342 & 283,793 & 428,875 & 414,720 & 162,774 \\
\hline Asterionella sp. & - & - & - & 10,616 & 12,031 & 1,415 & - & - & - \\
\hline Asterolamphalus sp. & - & 3,539 & 3,539 & - & - & - & - & - & - \\
\hline Amphiprora sp. & - & - & 1,415 & 1,415 & 708 & 708 & - & - & - \\
\hline Bacillaria sp. & 707.71 & 4,246 & 4,246 & 708 & - & - & - & - & - \\
\hline Bacteriastrum sp. & 708 & 11,323 & 12,031 & 1,415 & 708 & 11,323 & 10,616 & 10,616 & 10,616 \\
\hline Biddulphia sp. & 49,540 & 49,540 & 24,062 & 27,601 & 26,893 & 23,355 & 17,693 & 17,693 & - \\
\hline Chaetoceros sp. & 65,110 & 40,340 & 15,570 & 26,185 & 31,139 & 84,218 & 75,018 & 78,556 & 77,849 \\
\hline Climacodium sp. & - & - & - & 3,539 & 3,539 & - & - & - & - \\
\hline Climacosphenia sp. & - & - & 708 & 708 & - & - & - & - & - \\
\hline Cococcneis sp. & 2,831 & 2,831 & 708 & 4,246 & 4,246 & 708 & - & 17,693 & 17,693 \\
\hline Coscinodiscus sp. & $1,419,674$ & 53,786 & 163,482 & 184,713 & 84,926 & 53,079 & 220,807 & 224,345 & 3,539 \\
\hline Cylindroteca sp & - & - & - & 10,616 & 12,739 & 2,123 & - & 10,616 & 10,616 \\
\hline Diploneis sp. & - & - & 1,415 & 1,415 & - & - & 1,415 & 1,415 & - \\
\hline Dytilum sp. & 1,415 & 1,415 & 708 & 708 & - & - & - & - & - \\
\hline Fragillaria & 4,954 & 4,954 & 2,831 & 2,831 & - & - & - & - & - \\
\hline Guinardia sp. & - & - & - & - & - & - & 2,123 & 2,123 & - \\
\hline Hemiaulus sp. & - & - & - & 7,077 & 7,077 & - & - & - & - \\
\hline Lauderia sp. & - & - & - & - & - & - & 708 & 708 & - \\
\hline Leptocylindrus sp. & 7,077 & - & - & - & 708 & 14,862 & 14,154 & - & - \\
\hline Licmophora sp. & - & - & - & - & - & 14,154 & 14,154 & - & - \\
\hline Melosira sp. & 708 & 11,323 & 12,031 & 22,647 & 21,939 & 708 & 708 & 708 & - \\
\hline Navicula sp. & - & - & 708 & 708 & 4,246 & 4,246 & 3,539 & 3,539 & - \\
\hline Nitzchia sp. & 17,693 & 35,386 & 35,386 & 152,159 & 152,159 & 7,077 & 7,077 & - & - \\
\hline Pleurosigma sp. & 38,217 & 9,908 & 7,077 & 116,773 & 121,019 & 18,401 & 14,862 & 29,016 & 28,309 \\
\hline Rhizosolenia sp. & 10,616 & 14,154 & 10,616 & 17,693 & 11,323 & 708 & 2,123 & 5,662 & 3,539 \\
\hline Skeletonema sp. & 1,415 & 4,954 & 5,662 & 16,277 & 14,154 & 28,309 & 28,309 & 3,539 & 3,539 \\
\hline Strepthoteca sp. & 3,539 & 3,539 & 1,415 & 1,415 & 1,415 & 1,415 & - & - & - \\
\hline Surirella sp. & - & - & - & 3,539 & 3,539 & - & - & - & - \\
\hline Striatella sp. & - & 3,539 & 3,539 & 88,464 & 89,172 & 708 & - & - & - \\
\hline Triceratium sp. & 18,401 & 14,862 & 7,077 & 7,077 & 2,123 & 16,277 & 15,570 & 8,493 & 7,077 \\
\hline Thalassiothrix sp. & 708 & 708 & - & 3,539 & 3,539 & - & - & - & - \\
\hline DINOPHYCEAE & 30,432 & 5,662 & 4,246 & 7,785 & 8,493 & 4,954 & 3,539 & - & - \\
\hline Ceratium sp. & 30,432 & 5,662 & 3,539 & 7,077 & 8,493 & 1,415 & - & - & - \\
\hline Dinophysis sp. & - & - & 708 & 708 & - & 3,539 & 3,539 & - & - \\
\hline
\end{tabular}




\section{Sebaran Fitoplankton}

Sebaran kelimpahan fitoplankton terlihat pada Gambar 2. Terlihat bahwa kelimpahan fitoplankton tertinggi berturut-turut terdapat pada stasiun 9, stasiun 8 , stasiun 6 , stasiun 1 , stasiun 3 , stasiun 7 , stasiun 4, stasiun 2 dan terendah terdapat di stasiun 5 . Tingginya kelimpahan fitoplankton di stasiun 9 dapat disebabkan karena stasiun tersebut dekat dengan pemukiman penduduk dan stasiun 5 jauh dari pemukiman penduduk. Menurut Haumahu (2004) distribusi plankton yang tidak merata di perairan terjadi karena plankton merupakan organisme yang memiliki pola distribusi "patchy" (mengumpul) dan juga memiliki kemampuan bergerak yang lemah sehingga distribusinya akan bergantung pada pergerakan massa air dan juga dipengaruhi oleh arus, kandungan nutrient, suhu, kecerahan, angina, $\mathrm{pH}$, kekeruhan dan migrasi diurnal dari plankton itu sendiri (Sediadi, 2004). Tingginya kelimpahan fitoplankton pada stasiun 9 karena adanya masukan dari daratan selain itu diduga karena adanya sumbangan dari hutan mangrove dan dekat dengan pemukiman penduduk. Koesoebiono (1981) mengatakan bahwa konsentrasi unsur hara di perairan dekat pantai cenderung tinggi sebagai akibat adanya tambahan dari daratan melalui aliran sungai. Nitrat (NO3) adalah nutrien utama bagi pertumbuhan fitoplankton dan algae hal tersebut sesuai dengan pendapat Fried et al. (2003) yang menyatakan bahwa bahwa nitrat dan fosfat memiliki efek positif pada pertumbuhan alga

\section{SIMPULAN}

Kelimpahan fitoplankton di Teluk Gerupuk berkisar antara: 619.958 - 7.456.476 sel/1 yang terdiri dari 2 kelas fitoplankton yaitu: 1. Kelas Bacillariophycea: 32 jenis dan 2. Kelas Dinophyceae: 5 jenis yang dilakukan di 9 (sembilan) stasiun pengamatan dengan kelimpahan tertinggi di dominansi dari genus Chaetoceros sp. Keanekaragaman fitoplankton yang rendah dengan kisaran 0,24-98 dengan rata-rata $0,58 \pm 0,29$, dan keseragaman fitoplankton berkisar antara: 0,01-0,05 dengan rata-rata $0,03 \pm 0,02$ atau dengan kata lain $0<\mathrm{E}<0,5$ berarti komunitas fitoplankton tertekan.

\section{DAFTAR PUSTAKA}

Alpine, AE., Cloern, JE. 1988. Phytoplankton growth rates in a light-limited environment. San Fransisco Bay. Mar EcolProg Ser. 44; 167173.

American Public Health Association. 2005. Standard methods for the examination of water and waste water. 17th ed. Washington DC, USA. $1193 p$

Barbiero RP, Rockwell DC, Warren GJ, Tuchman ML. 2006. Changes in spring phytoplankton communities and nutrient dynamics in the eastern basin of Lake Erie since the invasion of Dreissena spp. Canadian Journal of Fisheries and Aquatic Sciences 63: 1549-1563

Basmi, J. 1999. Planktonologi : Bioekologi Plankton Algae. Tidak Dipublikasikan Fakultas Perikanan dan Ilmu Kelauan. IPB. Bogor. 110 hal.

Camargo, J.A., A. Alonso, and A. Salamanca. 2005. Nitrate toxicity to aquatic animals: a review with new data for freshwater invertebrates. Chemosphere, 58: 1255-1267

Chen, C.T.A. 2007. Nutrient cycling in the ocean; in: "Oceanography," ed. By J.C.J. Nihoul and C.T.A. Chen, in Encyclopedia of life support System (EOLSS), Developed under the Auspices of the UNESCO, Eolss Publiser, Oxford, UK, ISBN: 978-1-905839-62-9 eBook, Vol.1, 331-343

Depew DC, Guildford SJ, Smith REH. 2006. Nearshoreoffshore comparison of chlorophyll a and phytoplankton production in the dreissenid-colonized eastern basin of Lake Erie. Canadian Journal of Fisheries and Aquatic Sciences 63: 1115-1129

DiTullio GR, Hutchins DA, Bruland KW., 1993. Interaction of iron and major nutrients controls phytoplankton growth and species composition in the tropical North Pacific Ocean. Limnol Oceanogr 38:495-5

Dugdale RC, Wilkerson F. 1992. Nutrient limitation of new production in the sea. In: Falkowski PG. Woodhead AD (eds) Primary productivity and biogeochernical cycles in the sea. Plenum, New York, p 102-122

Effendi, H., 2003, Telaah kualitas air bagi pengelolaan sumber daya dan lingkungan perairan. Penerbit Kanisius. Yogyakarta. 257 hal

Fong, D.A dan W.R. Geyer. 2001. Respone of river plume during an upwelling favorable wind event. Journal of Geophysical ResearchOcean 106(1):1067-1084

Fried S, B. Mackie, and E. Nothwehr. 2003. Nitrate and phosphate levels positively affect the growth of algae species found in Perry Pond. Grinnell College. Tillers 4:21-24

Gunarto. 2004. Konservasi mangrove sebagai pendukung sumber hayati perikanan pantai. Jurnal Litbang Pertanian, 23(1):15-21

Graziano LM, Geider RJ, Li WKW, Olaizola M. 1996. Nitrogen limitation of North Atlantic phytoplankton: analysis of physiological condition in nutrient enrichment experiments. Aquat Microb Ecol 11:53-6

Hasle G.R. \& Syvertsen E.E. 1997. Marine diatoms. In: Identifying marine phytoplankton (Ed. by C.R. Tomas), pp. 5-385. Academic Press, San Diego

Haumau, S. 2005. Distribusi spasial fitoplankton di perairan teluk haria saparua Maluku tengah. Ilmu Kelautan. 10(3):126-134

Kalangi,P.N.I., K.W.A Masengi, M. Iwata, F.P.T Pangalila dan I.F. Mandagi. 2012. Profil 
salinitas dan suhu di Teluk Manado pada harihari hujan dan tidak hujan. Jurnal Perikanan dan Kelautan Tropis VIII(3): 90-93

Koesoebiono. 1981. Plankton dan Produktivitas Bahari. Institut Pertanian Bogor. Bogor

Mann, K.H \& C.G Lazier. 1991. Ecology of Coastal Water, a System Approach. Studies in Ecology Vol.8. University of California Press, Berkeley and Los Angeles.

Meirinawati, H dan Nurul Fitriya. 2018. Pengaruh konsentras nutrient terhadap kelimpahan Fitoplankton di perairan Halmahera-maluku. Oseanologi dan Limnologi di Indonesia 3(3): 183-195

Odum, Eugene P. 1993. Dasar-dasar Ekologi. Di perjemahkan oleh Tjahjono Samingan; penyunting B. Srigandono. Yogyakarta : Gadjah Mada University Press. 476 hal

Ornolfsdottir E.B., Lumsden S.E., and Pinckney J.L., 2004. Nutrient pulsing as a regulator of phytoplankton abundance and community composition in Galveston Bay, Texas. Journal of Experimental Marine Biology and Ecology, 303, 197-220

Panda,S.S , Dhal N K, \& Panda C R. 2012. Phytoplankton diversity in response to abiotic factors along Orissa coast, Bay of Bengal. International J Environm Sci (2) 3-8.

Purnamaningtyas, S.E, Dimas Angga Hedianto, dan Riswanto. 2017. Hubungan beberapa parameter fisika kimiawi dan fitoplankton Di pesisir kabupaten kubu raya, kalimantan barat. Jurnal Ilmu dan Teknologi Kelautan Tropis. Vol. 9 No. 2, Hlm. 727-737

Putri, M.R.A, S.T Hartati dan Fayakun Satria. 2016. Kematian massal ikan dan sebaran parameter

kualitas air di teluk jakarta. Bawal Widya Riset Perikanan Tangkap Volume 8 (2):77-90

Sanusi, H.S. 1994. Karakteristik Kimia dan Kesuburan Perairan Teluk Pelabuhan Ratu (tahap II-Musim Timur). Laporan Penelitian. Fakultas Perikanan dan Ilmu Kelautan. Institut Pertanian Bogor. Bogor. 89 hal

Sediadi. A. \& L.F. Wenno, 1995. Tingkat kesuburan dan kondisi hidrologi perairan mangrove Teluk Bintuni, Irian Jaya. Pros. Seminar V Ekosistem Mangrove.: 179-189.

Sediadi, A. 2004. Dominasi cyanobacteria pada musim peralihan di perairan Laut Banda dan sekitarnya. Makara Sains, 8(1), 1-14.

Setyobudiandi dan B. Priyono 2009. Sampling dan Analisis Data Perikanan dan Kelautan :Terapan Metode Pengambilan Contoh di Wilayah Pesisir dan Laut. Cetakan Pertama. Makaira FPIK IPB : Bogor. vi + 313 hal.

Sin Y, Wetzel L R, \& Anderson C I. 1999. Spatial and temporal characteristics of nutrient and phytoplankton dynamics in the York River Estuary, Virginia, Analyses of long-term data. Estuaries., 22, 260-275
Struyf, E., A. Smis, S. Van Damme, P. Meire, and D.J Conley. 2009. The Global biogeochemical silicon cycle. Silicon 1. 207-213

Johnson, W.S. dan D. M. Allen. 2005. Zooplankton of the Atlantic and Gulf Coast, A Guide to Their Identification and Ecology. The John Hopkins. Uviversity Press. Baltimore and London.

Konno S., Inoue N., Herna' Ndez-Becerril D.U. \& Jordan R.W. 2010. Chaetoceros affinis blooms in Palauan meromictic marine lake. Vie et Milieu 60: 257-264

Takano H. 1990. Diatoms. In: Red tide organisms in Japan - an illustrated taxonomic guide (Ed. by Y. Fukuyo, H. Takano, M. Chihara \& K. Matsuoka), pp. 162-331. Uchida Rokakuho, Tokyo

Qi Y.Z. 2008. Studies on red tides in the South China Sea. Guangdong Economic Press, Guangzhou. $566 \mathrm{pp}$ 